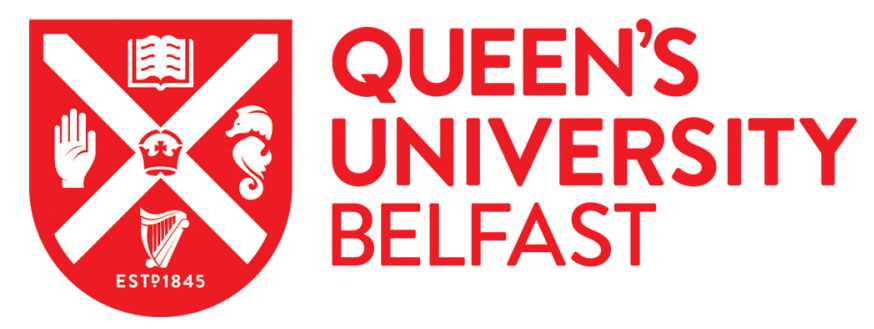

\title{
Family Focused Practice for families impacted by maternal mental illness and substance misuse in home visiting: A qualitative systematic review
}

Leonard, R. A., Linden, M., \& Grant, A. (2018). Family Focused Practice for families impacted by maternal mental illness and substance misuse in home visiting: A qualitative systematic review. Journal of Family Nursing, 24(2), 128-155. https://doi.org/10.1177/1074840718770612

Published in:

Journal of Family Nursing

Document Version:

Peer reviewed version

Queen's University Belfast - Research Portal:

Link to publication record in Queen's University Belfast Research Portal

\footnotetext{
Publisher rights

Copyright 2017 SAGE Publications. This work is made available online in accordance with the publisher's policies. Please refer to any applicable terms of use of the publisher.
}

\section{General rights}

Copyright for the publications made accessible via the Queen's University Belfast Research Portal is retained by the author(s) and / or other copyright owners and it is a condition of accessing these publications that users recognise and abide by the legal requirements associated with these rights.

\section{Take down policy}

The Research Portal is Queen's institutional repository that provides access to Queen's research output. Every effort has been made to ensure that content in the Research Portal does not infringe any person's rights, or applicable UK laws. If you discover content in the Research Portal that you believe breaches copyright or violates any law, please contact openaccess@qub.ac.uk. 


\section{Cover page}

Manuscript title: Family Focused Practice for families impacted by maternal mental illness and substance misuse in home visiting: A qualitative systematic review.

1. *Rachel Leonard rleonard08@qub.ac.uk

2. Dr Mark Linden, $\mathrm{PhD}^{\mathrm{a}}$

3. *Dr Anne Grant, $\mathrm{PhD}^{\mathrm{a}}$

*Corresponding author

aSchool of Nursing and Midwifery, Medical Biology Centre, Queen's University, 97 Lisburn Road, Belfast BT9 7BL

Funding. This review was completed for part-fulfilment of RL's PhD. No outside funding was used.

Conflict of interest. The authors declare no conflicts of interest.

Author contribution. RL and ML were responsible for the design of this systematic review, data acquisition, analysis and interpretation. AG aided in this process, arbitrating any disagreement. RL drafted the article. RL, ML and AG critically revised the manuscript. All authors approved the final submission.

Keywords

Family focused practice, Health visiting, Mental Illness, Public health nurse, Systematic review. 


\section{Biographical Information}

1. Rachel A. Leonard, is a PhD student in the School of Nursing and Midwifery at Queens University, Belfast, Northern Ireland. Her research focuses on family focused care and practices for maternal mental illness. In particular, she focuses on how professionals support families where there is maternal mental illness.

2. Dr Mark Linden, $\mathrm{PhD}$, is a lecturer in the School of Nursing and Midwifery at Queens University, Belfast, Northern Ireland. His research focuses on social inclusion in childhood survivors of brain injury. This includes a range of contextual factors that either help or hinder inclusion. These include the cognitive, social and environmental challenges that these children, and their families, deal with on a daily basis. His recent publications include:

Lohan, M., Aventin, Á, Maguire, L., Curran, R., Mcdowell, C., Agus, A., . . O’Halloran, P. (2017). Increasing boys' and girls' intentions to avoid teenage pregnancy: a cluster randomised controlled feasibility trial of an interactive video drama-based intervention in post-primary schools in Northern Ireland. Public Health Research, 5(1), 1-344. doi:10.3310/phr05010

Mckinlay, A., Linden, M., Depompei, R., Jonsson, C. A., Anderson, V., Braga, L., . . . Wicks, B. (2016). Service provision for children and young people with acquired brain injury: Practice recommendations. Brain Injury, 30(13-14), 1656-1664. doi:10.1080/02699052.2016.1201592 
Linden, M., Hawley, C., Blackwood, B., Evans, J., \& Anderson, V. (2014). Technological aids for the rehabilitation of memory and executive functioning in children and adolescents with acquired brain injury. Cochrane Database of Systematic Reviews. doi:10.1002/14651858.cd011020

3. Dr Anne Grant, PhD, RPN, is a lecturer in mental health in the School of Nursing and Midwifery at Queens University, Belfast, Northern Ireland and a registered psychiatric nurse. Her research and clinical interests include psychiatric nursing, parental mental illness, early interventions for families when parents have mental illness, and workforce capacity in relation to family-focused practice. Her recent publication include:

Foster, K., Maybery, D., Reupert, A., Gladstone, B., Grant, A., Ruud, T., . . Kowalenko, N. (2016). Family-focused practice in mental health care: An integrative review. Child \& Youth Services, 37(2), 129-155. doi:10.1080/0145935x.2016.1104048

Grant, A., \& Reupert, A. (2016). The Impact of Organizational Factors and Government Policy on Psychiatric Nurses' Family-Focused Practice With Parents Who Have Mental Illness, Their Dependent Children, and Families in Ireland. Journal of Family Nursing, 22(2), 199-223. doi:10.1177/1074840716643770

Maybery, D., Goodyear, M., Reupert, A. E., \& Grant, A. (2016). Worker, workplace or families: What influences family focused practices in adult mental health? Journal of Psychiatric and Mental Health Nursing, 23(3-4), 163-171. doi:10.1111/jpm.12294 
Family Focused Practice for families impacted by maternal mental illness and substance misuse in home visiting: A qualitative systematic review.

\begin{abstract}
Maternal mental illness is a major public health issue and can adversely affect the whole family. Increasingly, research and policy are recognising the benefits of a family focused approach to practice, an approach which emphasises the family as the unit of attention. This review was conducted with the aim of systematically analysing the qualitative literature surrounding health visitors' family focused practice, with mothers who have mental illness and/or substance misuse. Through the synthesis we developed three main findings: 1) parents' needs regarding health visitors' family focused practice, 2) the ambiguity of mental illness in health visiting, and 3) the challenges of family focused practice in health visiting. Above all, health visitors, families and mothers with mental illness experience many challenges in family focused practice, even though it is both desirable and beneficial. This calls for a deeper understanding of how family focused practice can be effectively practiced in health visiting.
\end{abstract}

\title{
Acknowledgement of Funding
}

This research received no specific grant from any funding agency in the public, commercial, or not-for-profit sectors. 
Maternal mental illness is a major public health issue (Bauer et al., 2014; Hogg, 2013; World Health Organsiation, 2015). Worldwide about ten percent of pregnant women and thirteen percent of women who have just given birth experience mental ill health, primarily depression (O’Hara \& Swain, 1996). In the United Kingdom (UK) it is estimated that, ten percent of mothers have a mental illness at any given time (Bee et al., 2014; Parker et al., 2008). In addition, the National Society for the Protection of Cruelty to Children (NSPCC) 'All Babies Count' report showed that in England approximately 122,000 babies under one year are living with a parent who has a mental illness (Cuthbert et al., 2011).

Whilst parenthood is an important life role, parental responsibilities may affect a mother's mental health and recovery (Acri \& Hoagwood, 2015; Foster et al., 2016). Maternal mental illness may also adversely impact children's cognitive, emotional, social, physical and behavioural development in both the short and long-term (Beardslee et al., 2012; Bee et al., 2014; Goodman \& Gotlib, 1999). Twenty-five to fifty percent of children who have a parent with a mental illness will experience some psychological disorder during childhood or adolescence, and ten to fourteen percent of these children will be diagnosed with a psychotic disorder at some point in their lives (Beardslee et al., 2012; van Doesum \& Hosman, 2009). Research also suggests that the adverse impacts are not limited to children (Baronet, 1999; Idstad et al., 2010; Iseselo et al., 2016; Ohaeri, 2002). The burden of care on partners and other adult family members has become increasingly recognised in research. This can place families and partners at increasing risk of psychological, emotional, social, physical and financial problems (Baronet, 1999; Idstad et al., 2010; Iseselo et al., 2016 Ohaeri, 2002). On this basis, families of mothers who have mental illness are recognised as a target group for early intervention (Reupert et al., 2012; Social Care Institute for Excellence, 2011).

Due to the impact mental illness can have on the whole family effective interventions must consider the needs of all family members through a whole family approach (Diggins, 
2011; Foster et al., 2016),. Family Focused Practice (FFP) improves outcomes for mothers and reduces the burden of care for families while providing a preventative and supportive function for children (Foster et al., 2012; Siegenthaler, Munder \& Egger, 2012). This approach emphasises the family as the unit of attention (Grant \& Reupert, 2016). FFP is defined in this study as an umbrella term encompassing a continuum of family focused activities (see Table 1). The term FFP is used interchangeably with 'whole family', 'familyoriented', 'family-sensitive' and 'family-centred' (Foster et al., 2012; Ward et al., 2017).

Public health is at the core of health visiting (National Institute for Clinical Excellence, 2014). Health visitors are registered nurses or midwives who have additional training in community public health nursing. Health visiting, a role which has been characterised by the practitioner - parent relationship (Cowley et al., 2015), makes significant contributions to the health and wellbeing of families. While the term 'health visitor' is mainly used in the UK, Denmark and Norway, there are similar professions internationally, such as, child health nurse in Sweden, public health nurse in the United States, Canada, Ireland and Finland, and child and family health nurse in Australia. Although some countries may take different policy approaches, all professions work in the context of public health, focusing particularly on early life (Cowley et al., 2013). The front-line position of health visitors in healthcare provision during the postnatal period, lends itself to their critical role in identification and early intervention for the improvement of parental and child mental health (Cummings \& Whittaker, 2016; Health Education England, 2016; Jenkins, 2015; Speier, 2015).

The terms 'mental health' and 'mental illness' are both commonly used throughout the literature. While the two terms are used interchangeably, mental health refers to an overall state of mental well-being, whereas mental illness refers to a recognised and diagnosable disorder, which may present as a “disturbance in an individual's cognition, emotion 
regulation, or behaviour that reflects a dysfunction in the psychological, biological, or developmental processes underlying mental functioning" (American Psychiatric Association, 2013). This difference then, implies that there are distinctive needs of both the individual and their family inherent to mental illness (Nicholson et al., 2001; Morris \& Stuart, 2002;). This paper is concerned with health visitors' FFP with mothers with mental illness and hence refers to the term 'mental illness' throughout, however this is done with consideration of the interchangeability of the two terms in the literature. Moreover, while we are interested in mothers who have both mental illness and substance misuse, for the purpose of this paper, we consider mental illness, to include substance misuse (National Institute on Drug Abuse, 2011).

The majority of research to date has explored FFP in mental health services (Grant \& Reupert, 2016; Maybery et al., 2016; Wong et al., 2016), addictions (e.g. Copello et al., 2000; Hampson, 2013), and social services (Hughes, 2010; Social Exclusion Task Force, 2007), with little attention given to health visitors' FFP with mothers who have mental illness and their families. Based upon this background, the purpose of this review was to synthesise and appraise qualitative studies exploring health visitors' FFP with mothers who have mental illness and their families. That is to say, that our primary focus of the review was FFP with maternal mental illness, and not child, adolescent or paternal mental illness. Therefore, the following research question guided the systematic review: what are the experiences of health visitors, mothers who have mental illness and their family members, in relation to health visitor's FFP? 


\section{Method}

\section{Electronic Sources and search strategy}

The Preferred Reporting Items for Systematic Reviews and Meta-Analyses (PRISMA) guidelines were used for the conduct and reporting of this systematic review (Moher et al., 2009). Five databases: CINAHL, Medline, PubMed, Web of Science and Maternity \& Infant Care, were systematically searched between October and November 2016, using a predetermined search strategy. Databases were chosen based on their access to a wide range of international articles in the relevant disciplines. Preliminary searches were conducted, which involved identifying literature relevant to the review question and extracting commonly used search terms. The terms that were included fell under three categories: mental illness; family focused practice; and health visiting. A wide range of alternative health visiting terms were included to capture all the relevant international literature. A full list of search terms can be found in Appendix 1 (see supplementary data).

The databases returned a total of 3,677 possible titles, which after removal of duplicates, left 3,537. Titles $(n=3,537)$ and abstracts $(n=393)$ were screened independently by two authors based on inclusion and exclusion criteria. Where there was uncertainty regarding the eligibility of a particular title or abstract the record was retained for full-text screening $(\mathrm{n}=120)$. Following review of the full-texts, thirteen qualitative and two mixed methods studies were identified. A PRISMA flow chart of this process can be found in Figure 1.

[Insert Figure 1] 


\section{Eligibility Criteria}

Criteria for inclusion in this review consisted of peer-reviewed empirical studies which were family focused, and observed FFP, or discussed experiences of FFP in relation to maternal mental illness and substance misuse, from the perspectives of either health visitors, mothers or family members. We screened the family focused literature to extract a continuum of family focused activities, relevant to health visiting. These were used to initially determine if a paper was family focused, and later used to rate the included studies (see Table. 1). The activities were agreed by the three reviewers. Studies that focused on mothers solely with substance misuse without the co-existence of a mental illness were included. As no resources were available for translation, only papers published in English were accepted for review.

Exclusion criteria included review articles, editorials, commentaries, and quantitative studies. Given the focus was on FFP with families impacted by maternal mental illness, studies which solely focused on child, adolescent or paternal mental illness were excluded. Studies that employed home-based practice not delivered by health visitors were excluded, along with studies that focused on community psychiatric nurses (specialist mental health nurses) or paraprofessionals (e.g. peer support home visiting or those connected to religious organisations). We defined health visiting to mean "a workforce of specialist community public health nurses who provide expert advice, support and interventions to families with children" (NHS Enlgand, 2014, p.5). While acknowledging the range of international terms used to describe the public health nursing profession, for clarity this review refers to the term 'health visitor' throughout this paper.

[Insert Table1] 


\section{Data extraction}

Data extraction was performed on all eligible studies, independently by three reviewers using a standardised data extraction template. Disagreements were resolved by discussion between the three review authors. Information extracted included (a) author, (b) year, (c) participant demographics, (d) study design, (e) phenomena of interest, (f) inclusion of family beyond the mother, (g) evidence of family focused practice, (h) description of mental illness and/or substance misuse, (i) data collection methods, (j) data analysis methods, and (k) findings.

\section{Quality appraisal}

Quality appraisal was conducted on all included studies, to assess rigour.

Methodological quality was rated independently by the three reviewers. Where disputes arose we attempted to resolve these by consensus. The "quality appraisal checklist - qualitative studies" (National Institute for Health and Care Excellence, 2012) was employed. This checklist consisted of fourteen criteria which related to methodological quality. Each item was rated "yes", "no" or "unclear". A total score was calculated by summing the "yes" items, giving each study a score between zero-fourteen. Studies scoring eight or above out of a possible fourteen were considered as having good methodological quality. Those scoring below this threshold were considered as having poor methodological quality.

In addition, studies were rated against key family focused activities. A total of thirteen activities were identified from the FFP literature, these were then ranked as high, medium and low practice through consultations and reference to previous FFP continuums (Maybery et al., 2015). High ranking family focused activities, such as assessment of family functioning as a whole, were given a score of five each. Medium activities, such as, support for partner and family members to help meet their own needs, were given a score of three 
Journal of Family Nursing (2018)

each. And finally low activities such as, supporting the mother-infant relationship, were given a score of one each. A total score for each study was calculated by summing the activities met, with a potential maximum score of thirty-nine, and potential minimum score of one. Full details of individual studies FFP rating are detailed in Appendix 2 (see supplementary data).

\section{Data synthesis.}

A narrative synthesis was conducted on all included studies (Popay et al., 2006). Narrative synthesis refers to 'an approach to the systematic review and synthesis of findings from multiple sources and relies primarily on the use of words and text to summarize and explain the findings of the synthesis' (Popay et al., 2006, p. 5). Following the guidelines of Popay et al., (2006), analysis of included studies consisted of firstly, extracting descriptive characteristics to produce a textual summary of results, as described in the data extraction phase. Secondly, each study was read and reviewed in-depth which enabled the exploration of relationships both within and between the studies. Finally, these relationships were compared and contrasted across the studies to identify themes relevant to FFP. Once the themes were identified, they were reviewed independently by a second reviewer. The findings of the synthesis were then presented in a way that 'tells the story' of the findings from included studies, as suggested by Popay et al., (2006).

\section{Results}

\section{Overview of included studies}

Twelve qualitative and three mixed methods studies published between 2005-2016 were included in the review. Seven studies were conducted in the UK, four in Australia, two in the USA, one in Finland and one in Sweden. The combined total of participants across the fifteen studies amounted to 571 individuals. Sample sizes ranged from one (Fletcher, 2009) to 
one hundred and sixty-eight (Orford, Templeton, Patel, Velleman, \& Copello, 2007). A breakdown of individual sample sizes and countries of origin are detailed in Table 2. The majority of participants in the studies were professionals: seven studies included health visitors, five included health visitors and other professionals, and two included health visitors and mothers. One study exclusively included fathers. Six of the studies reported generally on mental illness during the postpartum period, six studies reported specifically on postnatal depression and three studies reported on substance misuse.

[Insert Table 2]

\section{Quality assessment}

The overall average quality of included studies was nine, with scores ranging from two-twelve. Individual quality appraisal scores are detailed in Table 2. The majority of studies included a clearly stated research question, evident in fourteen of the studies. Failure to clearly detail the role of the researcher, study limitations and inadequate information on the data collection and analysis process were the most frequently observed methodological flaws.

\section{Synthesis of findings}

Through the narrative synthesis we developed three main themes: a) parents' needs regarding health visitors' FFP, b) the ambiguity of mental illness in health visiting, and c) challenges of family focused practice in health visiting. These were developed by extracting, and synthesising the findings from each individual study. The findings were then categorised into themes. Each theme is discussed below. 


\section{Parents' needs regarding health visitors' FFP}

Predominantly, parents expressed the desire for services that were flexible, (McIntosh \& Shute, 2007; Psaila et al., 2014; Rollans et al., 2013; Tammentie et al., 2013), reliable (Borglin et al., 2015), and family focused (Chew-Graham et al., 2009; Fletcher, 2009; McIntosh \& Shute 2007; Tammentie et al., 2013). Practice which elicits these qualities encourages the building of a trusting relationship (McIntosh \& Shute, 2007), disclosure of mental ill health (Tammentie et al., 2013), and engagement in services (McIntosh \& Shute, 2007). However, these qualities are underpinned by the power of the relationship between family and the health visitor (Chew-Graham et al., 2008; McIntosh \& Shute, 2007; Rollans et al., 2013; Zeanah et al., 2006). While this strong connection may result in mutual benefits (Chew-Graham et al., 2008; Rollans et al., 2013), the intense connection, particularly in emotionally challenging situations, could also potentially lead to issues with maintaining boundaries, which may lead to health visitors feeling overwhelmed, depleted and burnt out (Zeanah et al., 2006).

While studies (8 out of 15) reported the needs of parents, only two of those included mothers (Chew-Graham et al., 2009; McIntosh \& Shute, 2007) and only one included fathers (Fletcher, 2009), with the remainder exclusively focusing on professionals. While none of the studies provided accounts from both mothers and fathers, some still claimed to report the views of parents. For example, McIntosh \& Shute (2007) aimed to explore how the process of health visiting resulted in parents' perceptions of being supported, through semi-structured interviews with health visitors and mothers. While the authors acknowledge that they are primarily interested in health visitors' practice with mothers and their infants, the absence of fathers in their sample reduces the confidence to which their results provide an accurate 
account of parents' perspective of support. In addition, five of the studies reported the needs of parents from the health visitors' perspective. For example, Tammentie et al., (2013) found that flexibility in appointments helps mothers and families when they are not doing well. However, this finding would have been strengthened if the first-hand accounts of parents were also incorporated, in addition to the health visitors.

\section{The ambiguity of mental illness in health visiting}

There are many difficulties associated in the screening and identification of PND (Belle \& Willis, 2013; Borglin et al., 2015; Chew-Graham et al., 2009; Rollans et al., 2013; Tammentie et al., 2013; Zeanah et al., 2006). There appears to be ambivalence in the use of the term 'PND', with difficulties in distinguishing between normal post-pregnancy blues and PND (Chew-Graham et al., 2008; Chew-Graham et al., 2009). This creates complexity for diagnosis, as PND is not seen as a separate mental illness (Chew-Graham et al., 2008; ChewGraham et al., 2009). For some, a contributing factor to this complexity is health visitors' alternative understanding of PND, which is distinct from the dominant medical understanding: distinguished by the use of medication for treatment, offering a platform for a more holistic approach to practice (Belle \& Willis, 2013). However, this alternative understanding may be beneficial for the recognition of women who do not have diagnosable PND (Zeanah et al., 2006), as it is not restricted by medical definitions (Belle \& Willis, 2013). These challenges further add to the difficulties in the management of PND (ChewGraham et al., 2008; Fletcher, 2009; Whittaker et al., 2016; Zeanah et al., 2006).

Reorganisation and changes to the health visiting role are thought to contribute to the lack of clarity around roles and responsibilities for the management of PND (Chew-Graham et al., 2008). 
One of the most prominent issues facing health visiting was the current strain on resources ( Chew-Graham et al., 2008; LeCroy \& Whitaker, 2005; Orford et al., 2007; Whittaker et al., 2016), with a lack of resources for referral and limited numbers of health visitors. Consequently, lack of services for referral have heavily influenced health visiting, including, deterring health visitors from identifying Postnatal Depression (PND), as health visitor believe they do not have support to offer mothers with this condition (Chew-Graham et al., 2008).

\section{Challenges of family focused practice in health visiting}

While there may be certain difficulties in engaging in work with family members, there is no denial of its importance (Drennan \& Joseph 2005; Fletcher, 2009; Moy et al., 2007; Orford et al., 2007; Tammentie et al., 2013; Whittaker et al., 2016; Zeanah et al., 2006). Engaging with the family as a whole, is at the very core of FFP (Foster et al., 2016; Maybery et al., 2015; Ward et al., 2017). Effective FFP, entails health visitors taking a holistic approach to families, a flexible approach to practice, and drawing on family strengths (Tammentie et al., 2013).

While the importance of FFP is recognised amongst practitioners, effective implementation is not without its challenges (Moy et al., 2007; Whittaker et al., 2016; Zeanah et al., 2006). Fear of blame, and of child protection cases going 'wrong', has led to risk adverse management, defensive practice, and services driven by child protection agendas rather than family support needs (Whittaker et al., 2016). There is added complexity when mothers with mental illness, are also impacted by family risk factors, such as; domestic violence, lack of family and social support, financial difficulties or unstable accommodation (Zeanah et al., 2006). Health visitors may also be faced with ethical dilemmas, when the 
rights of the child conflict with the rights of the parent (Moy et al., 2007); in which the health visitor must address and prioritise multiple and sometimes conflicting needs. Fleckhenderson, (2000) suggest that when the mother and child are both at risk, professionals need to 'see double' (p. 333) and to consider needs of both parties and draw upon knowledge and values of both a child protection and women's advocacy perspective. These challenges are further compounded by health visitors feeling ill-equipped to deal with the complex issues of mental illness and substance misuse (Moy et al., 2007; Orford et al., 2007; Zeanah et al., 2006). In order to promote FFP, further specialist mental illness training is needed (Drennan \& Joseph, 2005; Moy et al., 2007; Orford et al., 2007; Tammentie et al., 2013; Zeanah et al., 2006).

Challenges of whole family working in health visiting is further compounded by the lack of a clear definition of FFP and inconsistent application of the term. For example, Moy et al. (2007) explored the challenges identified by health professionals working with families who misuse drugs in relation to family parenting responsibilities, referring to the term 'family focused support'. While they provide justification of the importance of working with the whole family, and clear aims and objectives of the study, they provide no definition of the term 'family focused support'. The absence of a definition limits the conceptualisation of the term for further research.

\section{Discussion}

This paper has presented the findings of a qualitative systematic review of the literature on health visitors' FFP with mother who have mental illness and their families. Through our review three main themes were developed: parents' needs and health visiting, 
the ambiguity of mental illness in health visiting, and the challenges of family focused practice in health visiting. Further exploration of the themes identified problematic areas for consideration. Namely, the limited views of service users, a lack of distinction between mental health and mental illness, and a lack of continuity in how family focused practice is defined. Each of which will be looked at in turn.

One of the main findings to be highlighted in the review, was the desire for services that were flexible, (McIntosh \& Shute, 2007; Psaila et al., 2014; Rollans et al., 2013; Tammentie et al., 2013), reliable (Borglin et al., 2015), and family focused (Chew-Graham et al., 2009; Fletcher, 2009; McIntosh \& Shute 2007; Tammentie et al., 2013). While this theme considered parents' needs, further exploration highlighted the limited views of service users, with those providing parents perspectives, mainly doing so from the single account of mothers. This approach could be considered inadvisable due to the loss of important individual characteristics. A family systems perspective posits that families are complex units composed of individuals with different experiences and needs (Marks, Chun Bun \& McHale, 2009). Therefore, it is helpful to identify a series of stakeholders who may have differing perspectives of the family unit (Rose, \& Thornicroft, 2006); each reality making complete sense to the participant who sees it (Chen \& Wong, 2007). This approach can be used to highlight multiple and possibly heterogeneous viewpoints, and representations and roles (Chen \& Wong, 2007), that may be partial, limited and perhaps distorted when a single, combined perspective is adopted (Wilber, 2001).

Mental illness is without doubt a sensitive topic to discuss during research (Morris \& Stuart, 2002; Woodall et al., 2010), and an issue that impacts family members in different ways. This brings to light the appropriateness of reporting the views of parents, on the basis of data collected solely from mothers. In addition, in the exploration of health visitors' FFP, consideration must be given to the varying degrees to which mothers and fathers may be 
supported. While there have been attempts to improve health visitors' engagement with fathers, it is widely acknowledged that health visitors primarily work with mothers (Bateson et al., 2017; Cowley et al., 2013; Humphries \& Nolan, 2015), thus their experiences of practice will vary. In addition, individual characteristics may be lost when a parents' perspective is reported through the professionals' perspective. For example, the first-hand experiences of service users may become diluted if captured through a secondary source (e.g. health visitors) (Beresford, 2013; Mjosund et al., 2016). That is not to say that the health visitors' perspective is not of value. However, what may be more advisable is to use a multiperspective approach to research (Mjosund et al., 2016).

A further finding was that the majority of the studies (12 out of 15) focused on general maternal mental health or PND, while few explored diagnosed mental illnesses (e.g. postpartum psychosis, bipolar, PSTD) during the postnatal period or those that pre-dated pregnancy, including enduring mental illness. It is acknowledged that is it not within the role of the health visitor to diagnosis mental illness, however their role will ultimately vary in accordance to whether the mother is mentally healthy or has a mental illness. Studies which focused on general mental health did not account for the distinction between the terms 'mental health' and 'mental illness' (e.g... Zeanah et al., 2006). While the two terms are used interchangeably, mental health refers to an overall state of mental well-being, whereas mental illness refers to a recognised and diagnosable disorder. In addition, due to the distinct needs of both the individual with mental illness and their family (Morris \& Stuart, 2002; Nicholson et al., 2001), perspectives of needs, the health visitors role and FFP may differ in accordance to whether the person is mentally healthy or has a mental illness.

While it is acknowledged that there is a high prevalence of PND (Bauer et al., 2014), consideration should be given to examination of PND in isolation from other mental illnesses. For example, studies that explored PND provided limited information on the included 
mother's duration or stage of PND (Chew-Graham et al., 2009; Rollans et al., 2013). By doing so, it is unclear whether they have accounted for the thirty percent of women who remain unwell beyond the first year of childbirth, and those at high risk of subsequent postnatal and non-postnatal relapse (Cooper et al., 2009; Goodman, 2004), limiting the replicability for further research. Similarly, by not considering other mental illnesses, studies have not accounted for the heightened risk of relapse for those with bipolar disorder and psychosis following childbirth, with those with bipolar disorder having a one in five risk of recurrence within the first few months of childbirth (Di Florio, 2013; Munk-Olsen, 2009). In addition, viewing PND in isolation may imply that PND is distinct from depression. However, the postnatal period can be both a time when depression first presents or maybe a recurrence of pre-existing depression, with both referred to as PND ( Jones, 2012; Perfetti, Clark and Fillmore, 2004). This is further supported by confusion in the classification of psychiatric disorders during the postpartum period. The Diagnostic and Statistical Manual of Mental Disorders (DSM) and the International Classification of Diseases (ICD) state that PND and postnatal psychosis are not separate nosolgical entities, but merely represent episodes of mood disorder triggered by childbirth (Florio \& Meltzer-brody, 2015; Jones, 2012). When considering FFP, an exclusive focus on PND does not reflect the broad range of mental illnesses that impact both mothers and families. With evidence suggesting that while there is heightened risk associated with some types of mental illness following childbirth, the risk is more associated with onset, severity, and duration of the mental illness (Goodman \& Gotlib, 1999; Mattejat \& Remschmidt, 2008). Recognising the problematic distinction between pre-existing mental illness and those with peripartum onset, it is advisable to be inclusive when considering a range of mental illness.

A final finding of this review suggests that whilst all studies considered the importance of holistic care, few studies included an explicit definition. Although all the 
studies discussed FFP at some level, rating the studies against FFP activities would suggest that the studies explored lower levels of FFP (e.g. discussing family issues with mothers on their own). While the studies in this review may suggest that current health visiting is less family focused, the lack of consistency and continuity of a definition, limits the conclusions that can be drawn. The lack of conceptual clarity of FFP is further evidenced by the inconsistent terminology employed within the studies, with only one of the studies employing the term 'FFP' (Moy et al., 2007). Foster et al. (2016) similarly report this problem within the mental health literature highlighting the lack of a consistent definition. An agreed upon definition is necessary to provide clarity to future research endeavours.

\section{Limitations}

Although all reviewers were consistent in their application of the inclusion criteria for FFP during screening, the term FFP does not have a standardised definition, and is used interchangeably with other terms. We addressed this limitation by using theoretical frameworks of FFP and scoping the literature, which provided common principles and activities to which we could develop inclusion criteria. The activities in Table 1. are based upon theoretical frameworks and existing literature (Foster et al., 2016; Grant \& Reupert, 2016; Grant et al., 2016; Hogg, 2013; Morris et al., 2008). As no resources were available for translation, only papers published in English were accepted in the review. It is therefore possible that some of the international literature on home visiting and FFP with mothers who have a mental illness may have been missed. This could also explain the over representation of studies from higher income countries. 


\section{Recommendations and conclusions}

This review has highlighted the need for further studies to explore FFP in health visiting, eliciting a standardised definition of FFP. The majority of studies included in this review focused on either health professionals or mothers' perceptions of FFP, while there was a lack of the partners' perspective. Further research should adopt a multi-perspective approach to FFP in health visiting, which examines the perspectives of health visitors, mothers and partners' within the one study. Further research should explore health visitors' FFP with both mothers who have postnatal mental illness and pre-existing mental illness. Greater collaboration in research is needed to embed research about health visiting within wider disciplines of research to strengthen it academically and enable a deeper understanding of the contribution and context in which health visitor's FFP takes place.

Health visitors working with mothers with mental illness should consider the family as a whole, not just as a support for the mother but as service users in their own right. Health visitors should offer flexible services, emphasising the relationship between professional and family and actively listening to the concerns of all family members. Although the studies in this review mostly considered PND, health visitors should be aware that this is not the only mental illness to impact women in the postnatal period; those with pre-existing mental illness are also at risk. Health visitors working with families impacted by maternal mental illness should undertake more training to expand their knowledge and skills when working with a range of mental illnesses. Barriers such as limited resources, increased caseloads and risk adverse practice should be addressed, to facilitate health visitors to engage in more sophisticated levels of FFP.

This paper has presented the findings of a systematic review of the literature on health visitors' FFP with families impacted by maternal mental illness and substance misuse. Above 
all, health visitors, families and mothers with mental illness experience many challenges in relation to FFP, despite the fact it is both desirable and beneficial. While barriers to FFP have been identified, there is little known about what facilitates and enables FFP in health visiting. Maternal mental illness is a major world-wide public health issue, impacting many children and families. Despite the challenges faced by health visitors in delivering FFP, it has been shown to be beneficial, having short and long term successful outcomes. However, stretched resources and limited specialised training have added to the burden on existing services. This increasing burden calls into question the ability of health visitors to engage in meaningful FFP. Thus, there is a need for a deeper understanding of how family focused practice can be effectively practiced in health visiting, in the context of these challenges.

\section{Declaration of Conflicting interests}

The authors declare no potential conflicts of interest with respect to the research, authorship, and/or publication of this article.

\section{Funding}

This review was completed for part-fulfilment of RL's PhD. No outside funding was used. 
Journal of Family Nursing (2018)

\section{References}

Acri, M. C., \& Hoagwood, K. E. (2015). Addressing Parental Mental Health Within Interventions for Children: A Review. Research on Social Work Practice, 25(4), 395 401. doi:10.1177/1049731514546027

Bateson, K., Darwin, Z., Galdas, P., \& Rosan, C. (2017). Engaging fathers : Acknowledging the barriers. Journal of Health Visiting, 5(3), 126-132. doi:10.12968/johv.2017.5.3.126

Bauer, A., Parsonage, M., Knapp, M., Iemmi, V., Adelaja, B., \& Hogg, S. (2014). The costs of perinatal mental health problems (Rep. No. 4373019.). (2014). London : Centre for Mental Health. Retrieved from https://www.nwcscnsenate.nhs.uk/files/3914/7030/1256/Costs_of_perinatal_mh.pdf

Beardslee, W. R., Solantaus, T. S., Morgan, B. S., Gladstone, T. R., \& Kowalenko, N. M. (2012). Preventive interventions for children of parents with depression: international perspectives. MJA Open, 1(Suppl 1), 23-25. doi:10.5694/mjao11.11289

Bee, P., Bower, P., Byford, S., Churchill, R., Calam, R., Stallard, P., . . Abel, K. (2014). The clinical effectiveness, cost-effectiveness and acceptability of community-based interventions aimed at improving or maintaining quality of life in children of parents with serious mental illness: a systematic review. Health Technology Assessment, 18(8). doi:10.3310/hta18080

Belle, M., \& Willis, K. (2012). Professional practice in contested territory: Child Health Nurses and maternal sadness. Contemporary Nurse, 3176-3201. doi:10.5172/conu.2012.3176

Borglin, G., Hentzel, J., \& Bohman, D. M. (2015). Public health care nurses' views of 
mothers' mental health in paediatric healthcare services: a qualitative study. Primary Health Care Research \& Development, 16(05), 470-480. doi:10.1017/s1463423615000055

Chen, P. P., \& Wong, L. Y. (2007). Active conceptual modeling of learning: next generation learning-base system development. Berlin: Springer-Verlag.

Chew-Graham, C. A., Sharp, D., Chamberlain, E., Folkes, L., \& Turner, K. M. (2009). Disclosure of symptoms of postnatal depression, the perspectives of health professionals and women: a qualitative study. BMC Family Practice, 10(1). doi:10.1186/1471-2296-10-7

Chew-Graham, C., Chamberlain, E., Turner, K., Folkes, L., Caulfield, L., \& Sharp, D. (2008). GPs and health visitors views on the diagnosis and management of postnatal depression: a qualitative study. British Journal of General Practice, 58(548), 169-176. doi:10.3399/bjgp08x277212

Cooper, P. J., Tomlinson, M., Swartz, L., Landman, M., Molteno, C., Stein, A., ... Murray, L. (2009). Improving quality of mother-infant relationship and infant attachment in socioeconomically deprived community in South Africa: randomised controlled trial. BMJ (Clinical Research Ed.), 338, b974. doi:10.1136/bmj.b1858

Copello, A., Templeton, L., Krishnan, M., Orford, J., \& Velleman, R. (2000). A treatment package to improve primary care services for relatives of people with alcohol and drug problems. Addiction Research, 8(5), 471-484. doi:10.3109/16066350009005591

Cowley, S., Whittaker, K., Grigulis, A., Malone, M., Donetto, S., Wood, H., .. Maben, J. (2013). Why Health Visiting? A review of the literature about key health visitor interventions, processes and outcomes for children and families. (Rep. No. 016 0058). (Feb 2013). London : National Nursing Research Unit. Retrived from 
Journal of Family Nursing (2018)

https://www.kcl.ac.uk/nursing/research/nnru/publications/Reports/Why-HealthVisiting-NNRU-report-12-02-2013.pdf

Cowley, S., Whittaker, K., Malone, M., Donetto, S., Grigulis, A., \& Maben, J. (2015). Why health visiting? Examining the potential public health benefits from health visiting practice within a universal service: A narrative review of the literature. International Journal of Nursing Studies, 52(1), 465-480. doi:10.1016/j.ijnurstu.2014.07.013

Cummings, E., \& Whittaker, K. (2016). Listening visits by health visitors as an intervention for mild-to-moderate postnatal depression or anxiety. Journal of Health Visiting, 4(5). doi:10.12968/johv.2016.4.5.264

Diggins, M. (2011). Think Child, Think Parent, Think Family: A Guide to Parental Mental Health and Child Welfare. London: Social Care Institute of Excellence, (December 2011), 1-100. Retrieved from https://www.scie.org.uk/publications/guides/guide30/files/guide30.pdf

Drennan, V. M., \& Joseph, J. (2005). Health visiting and refugee families: issues in professional practice. Journal of Advanced Nursing, 49(2), 155-163. doi:10.1111/j.1365-2648.2004.03282.x

Dunn, L. B., Empowerment, S. L., \& Hadley, W. B. (2015). Addressing Risks to Advance Mental Health Research. JAMA Psychiatry, 70(12), 1363-1371. doi:10.1001/jamapsychiatry.2013.2105

Fleck-henderson, A. (2000). Domestic violence in the Child Protection System : Seeing Double. Children andYouth Services Review, 22(5), 333-354. doi:10.1016/s01907409(00)00084-0

Fletcher, R. (2009). Promoting Infant Well-being in the Context of Maternal Depression by 
Journal of Family Nursing (2018)

Supporting the Father. Infant Mental Health Journal, 30(1), 95-102. doi:10.1002/imhj.20205

Florio, A. Di, \& Meltzer-brody, S. (2015). Is Postpartum Depression a Distinct Disorder? Current Psychiatry Reports, 17(76), 1-6. doi:10.1007/s11920-015-0617-6

Foster, K., Maybery, D., Reupert, A., Gladstone, B., Grant, A., Ruud, T., . . Kowalenko, N. (2016). Family-focused practice in mental health care: An integrative review. Child \& Youth Services, 37(2), 129-155. doi:10.1080/0145935x.2016.1104048

Goodman, J. H. (2004). Paternal postpartum depression, its relationship to maternal postpartum depression, and implications for family health. Journal of Advanced Nursing, 45(1), 26-35. doi:10.1046/j.1365-2648.2003.02857.x

Goodman, S. H., \& Gotlib, I. H. (1999). Risk for psychopathology in the children of depressed mothers: a developmental model for understanding mechanisms of transmission. Psychological Review, 106(3), 458-90. doi:10.1037/0033$295 x .106 .3 .458$

Grant, A., Goodyear, M., Maybery, D., \& Reupert, A. (2016). Differences Between Irish and Australian Psychiatric Nurses' Family-Focused Practice in Adult Mental Health Services. Archives of Psychiatric Nursing, 30(2), 132-137. doi:10.1016/j.apnu.2015.07.005

Grant, A., \& Reupert, A. (2016). The Impact of Organizational Factors and Government Policy on Psychiatric Nurses' Family-Focused Practice With Parents Who Have Mental Illness, Their Dependent Children, and Families in Ireland. Journal of Family Nursing, 22(2), 199-223. doi:10.1177/1074840716643770

Häggman-Laitila, A. (2005). Families’ experiences of support provided by resource-oriented 
family professionals in Finland. Journal of Family Nursing, 11(3), 195-224. doi:10.1177/1074840705278488

Hampson, C. L. (2012). Integrating family-focused practice into routine addiction services (Unpublished master's thesis).

Health Education England. (2016). Specialist Health Visitors in Perinatal \& Infant Mental Health., National Health Service (March 2016). Retrieved from https://hee.nhs.uk/sites/default/files/documents/Specialist $\% 20 H e a l t h \% 20$ Visitors\%20i n\%20Perinatal\%20and\%20Mental\%20Health\%20FINAL\%20low\%20res.pdf

Hogg, S. (2013). Prevention in mind All Babies Count: Spotlight on Perinatal Mental Health (Publication). NSPCC. Retrieved from http://www.nspcc.org.uk/Inform/resourcesforprofessionals/underones/spotlightmental-health_wdf96656.pdf

Hughes, N. (2010). Models and Approaches in Family-Focused Policy and Practice. Social Policy and Society, 9(4), 545-555. doi:10.1017/S1474746410000266

Humphries, H., \& Nolan, M. (2015). Evaluation of a brief intervention to assist health visitors and community practitioners to engage with fathers as part of the healthy child initiative. Primary Health Care Research \& Development, 16, 367-376. doi:10.1017/S1463423615000031

Idstad, M., Ask, H., \& Tambs, K. (2010). Mental disorder and caregiver burden in spouses: the Nord-Trøndelag health study. BMC Public Health, 10(1). doi:10.1186/1471-2458$10-516$

Iseselo, M. K., Kajula, L., \& Yahya-Malima, K. I. (2016). The psychosocial problems of families caring for relatives with mental illnesses and their coping strategies: a 
qualitative urban based study in Dar es Salaam, Tanzania. BMC Psychiatry, 16(1), 146. doi:10.1186/s12888-016-0857-y

Jenkins, M. (2015). Substance use: The role of the health visitor in supporting families. Journal of Health Visiting, 3(7), 374-380. doi:10.12968/johv.2015.3.7.374

Jones, I. (2012). Women with severe mental illness. In A Textbook of Preconceptional Medicine and Management (pp. 171-180). Carlisle: Sapiens Publishing Ltd.

LeCroy, C. W., \& Whitaker, K. (2005). Improving the quality of home visitation: An exploratory study of difficult situations. Child Abuse \& Neglect, 29(9), 1003-1013. doi:10.1016/j.chiabu.2005.04.003

Family Patterns of Gender Role Attitudes.

Mattejat, F., \& Remschmidt, H. (2008). The Children of Mentally Ill Parents. Deutsches Arzteblastt International, 105(23), 413-418. doi:10.3238/arzteb1.2008.0413

Maybery, D., Foster, K., Goodyear, M., Grant, A., Tungpunkom, P., SkogøY, B. E., \& Lees, R. (2015). How can we make the psychiatric workforce more family focused? Parental Psychiatric Disorder, 301-311. doi:10.1017/cbo9781107707559.029

Maybery, D., Goodyear, M., Reupert, A. E., \& Grant, A. (2016). Worker, workplace or families: What influences family focused practices in adult mental health? Journal of Psychiatric and Mental Health Nursing, 23(3-4), 163-171. doi:10.1111/jpm.12294

McIntosh, J., \& Shute, J. (2007). The process of health visiting and its contribution to parental support in the Starting Well demonstration project. Health \& Social Care in the Community, 15(1), 77-85. doi:10.1111/j.1365-2524.2006.00676.x

Morris, J. A., \& Stuart, G. W. (2002). Training And Education Needs Of Consumers, Families, And Front-Line Staff In Behavioral Health Practice. Administration and 
Journal of Family Nursing (2018)

Policy in Mental Health, 29(May), 377-402. doi:10.1023/A:1019605207356

Morris, K., Hughes, N., Clarke, H., Tew, J., Mason, P., Galvani, S., ... Loveless, L. (2008). Think family: a literature review of whole family approaches (Rep. No. 07115 04814). Great Britain : Cabinet Office. Social Exclusion Task Force. Retrieved from http://dera.ioe.ac.uk/id/eprint/7373

Moy, C., Bayliss, M., \& Firth, J. (2007). Drug using parents: an exploration of family focused support from health professionals. Journal of Research in Nursing, 12(5), 551-561. doi:10.1177/1744987107079594

Mullins, J. L., Cheung, J. R., \& Lietz, C. A. (2012). Family preservation services: incorporating the voice of families into service implementation. Child \& Family Social Work, 17(3), 265-274. doi:10.1111/j.1365-2206.2011.00777.x

National Institute for Clinical Excellence. (2014). Health Visiting: NICE local government briefing, (September 2014: LGB22), 1-13. Retrieved from https://www.nice.org.uk/guidance/lgb22/resources/health-visiting-pdf60521203534021

National Institute for Health and Care Excellence. (2012). Methods for the development of NICE public health guidance (third edition) (Issue brief No. PMG4). Retrieved from https://www.nice.org.uk/guidance/pmg4/resources/methods-for-the-development-ofnice-public-health-guidance-third-edition-pdf-2007967445701

National Institute on Drug Abuse. (2011). Comorbidity: Addiction and Other Mental Illnesses. Research Report Series. Retrieved from https://d14rmgtrwzf5a.cloudfront.net/sites/default/files/rrcomorbidity.pdf

NHS Enlgand. (2014). National Health Visiting Service Specification (March 2014). 
Journal of Family Nursing (2018)

Retrieved from https://www.england.nhs.uk/wp-content/uploads/2014/03/hv-servspec.pdf

Nicholson, J., Ph, D., Biebel, K., Hinden, B., Ph, D., Henry, A., \& Sc, D. (2001). Critical issues for parents with mental illness and their families. Rockville, MD: University of Massachusetts Medical School.

O’Hara, M. W., \& Swain, A. M. (1996). International Review of Psychiatry Rates and risk of postpartum depression — a meta- analysis Rates and risk of postpartum depression. International Review of Psychiatry, 8(1), 37-54. doi:10.3109/09540269609037816

Orford, J., Templeton, L., Patel, A., Velleman, R., \& Copello, A. (2007). The 5-step family intervention in primary care: II. The views of primary healthcare professionals. Drugs-Education Prevention and Policy, 14(2), 117-135. doi:10.1080/09687630600997477

Parker, G., Beresford, B., Clarke, S., Gridley, K., Pitman, R., \& Spiers, G. (2008). Technical report for SCIE Research Review on the prevalence and incidence of parental mental health problems and the detection, screening and reporting of parental mental health problems (Working paper No. SCIE 2247 ). (2008). York: Social Policy Research Unit. Retrieved from https://www.york.ac.uk/inst/spru/research/pdf/SCIEReview1.pdf

Perfetti, J., Clark, R., \& Fillmore, C.-M. (2004). Postpartum depression: identification, screening, and treatment. WMJ : Official Publication of the State Medical Society of Wisconsin, 103(6), 56-63. http://www.ncbi.nlm.nih.gov/pubmed/15622821

Popay, J., Roberts, H., Sowden, A., Petticrew, M., Arai, L., Rodger, M., ... Duffy, S. (2006). Guidance on the Conduct of Narrative Synthesis in Systematic Reviews A Product from the ESRC Methods Programme. 
Psaila, K., Fowler, C., Kruske, S., \& Schmied, V. (2014). A qualitative study of innovations implemented to improve transition of care from maternity to child and family health (CFH) services in Australia. Women and Birth, 27(4).

doi:10.1016/j.wombi.2014.08.004

Rollans, M., Schmied, V., Kemp, L., \& Meade, T. (2013). Negotiating policy in practice: child and family health nurses' approach to the process of postnatal psychosocial assessment. BMC Health Services Research, 13, 133. doi:10.1186/1472-6963-13-133

Rose, D., Thornicroft, G., \& Slade, M. (2006). Who decides what evidence is? Developing a multiple perspectives paradigm in mental health. Acta Psychiatrica Scandinavica, 113(S429), 109-114. doi:10.1111/j.1600-0447.2005.00727.x

Siegenthaler, E., Munder, T., \& Egger, M. (2012). Effect of Preventive Interventions in Mentally Ill Parents on the Mental Health of the Offspring : Systematic Review and. Journal of the American Academy of Child \& Adolescent Psychiatry, 51(1), 8-17.e8. doi:10.1016/j.jaac.2011.10.018

Social Exclusion Task Force. (2007). Reaching out: think family: analysis and themes from the Families At Risk Review. London: Cabinet Office, UK Government. Retrieved from http://dera.ioe.ac.uk/id/eprint/7603

Tammentie, T., Paavilainen, E., Åstedt-Kurki, P., \& Tarkka, M. (2013). Public health nurses in Finland help to prevent postnatal depression. Primary Health Care, 23(1), 26-31. doi:10.7748/phc2013.02.23.1.26.e724

van Doesum, K. T., \& Hosman, C. M. (2009). Prevention of emotional problems and psychiatric risks in children of parents with a mental illness in the Netherlands: I. Interventions. Advances in Mental Health, 8(3), 264-276. doi:10.5172/jamh.8.3.264 
Ward, B., Reupert, A., McCormick, F., Waller, S., \& Kidd, S. (2017). Family-focused practice within a recovery framework: practitioners' qualitative perspectives. $B M C$ Health Services Research, 17(1), 234. doi.10.1186/s12913-017-2146-y

Whittaker, A., Williams, N., Chandler, A., Cunningham-Burley, S., McGorm, K., \& Mathews, G. (2016). The burden of care: a focus group study of healthcare practitioners in Scotland talking about parental drug misuse. Health \& Social Care in the Community, 24(5), 72-80. doi:10.1111/hsc.12249

Wong, O. L., Wan, E. S. F., \& Ng, M. L. T. (2016). Family-centered care in adults' mental health: Challenges in clinical social work practice. Social Work in Mental Health, 2985(October), 1-20. doi:10.1080/15332985.2015.1038413

Woodall, A., Morgan, C., Sloan, C., \& Howard, L. (2010). Barriers to participation in mental health research: are there specific gender, ethnicity and age related barriers? BMC Psychiatry, 10(1). doi:10.1186/1471-244x-10-103

World Health Organsiation. (2015). Thinking healthy: A manual for psychosocial management of perinatal depression version 1.0. (ISBN: 9789754004113) Geneva: WHO. Retrieved from http://apps.who.int/iris/bitstream/10665/152936/1/WHO_MSD_MER_15.1_eng.pdf

Zeanah, P. D., Larrieu, J. A., Boris, N. W., \& Nagle, G. A. (2006). Nurse home visiting: Perspectives from nurses. Infant Mental Health Journal, 27(1), 41-54. doi:10.1002/imhj.20079 


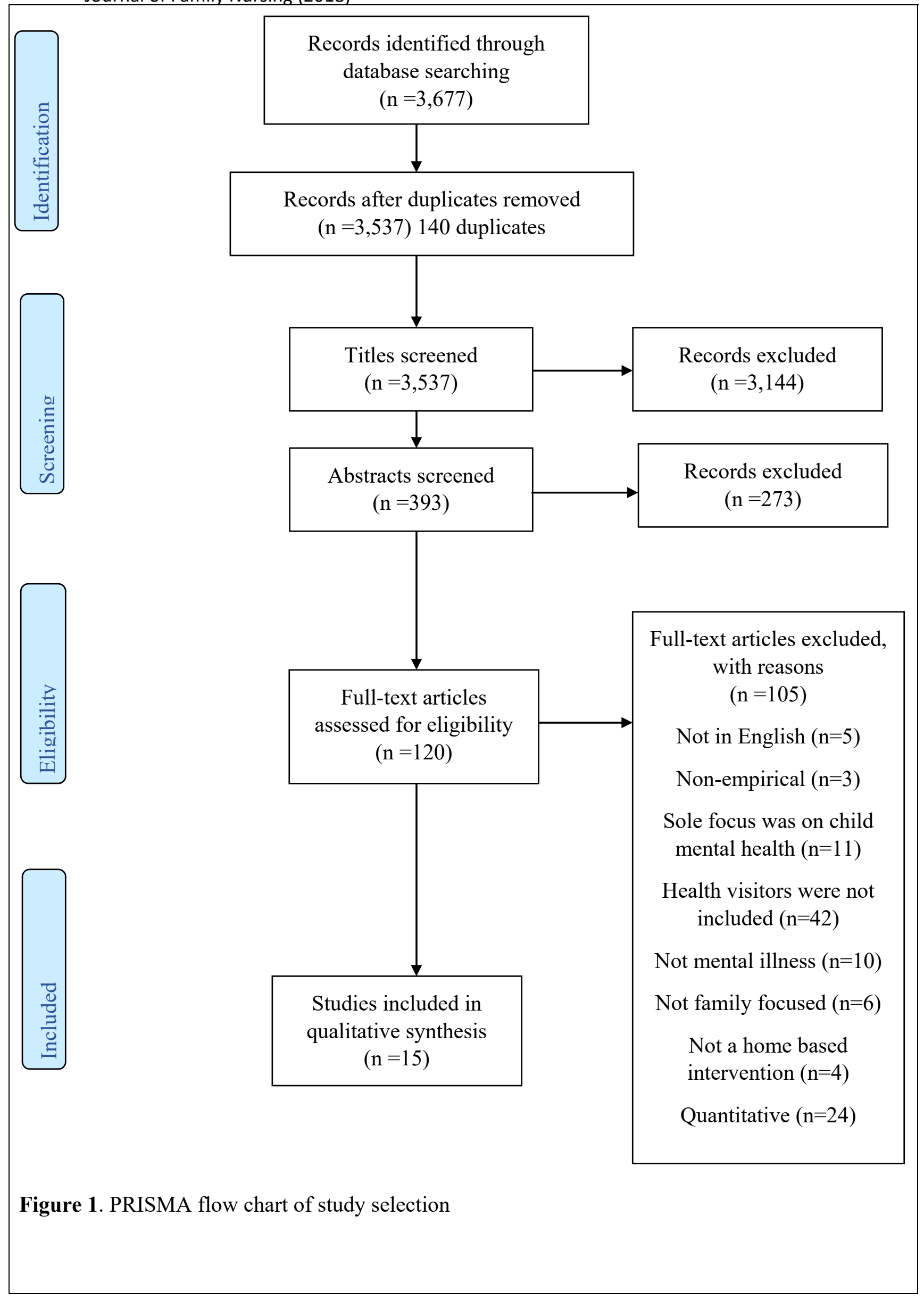


Table 1: FFP activities divided into low, medium and high categories of practice

\begin{tabular}{|c|c|}
\hline Rank & Activities \\
\hline \multirow[t]{4}{*}{ High } & Assessment of family* functioning as a whole; \\
\hline & $\begin{array}{l}\text { Engage in work with the family as a whole. Which may include work such as; } \\
\text { "Wraparound' services aim at all family members* and family case } \\
\text { management; }\end{array}$ \\
\hline & $\begin{array}{l}\text { Family inclusive mother and baby units, such as facilities and support also } \\
\text { provided for partners; }\end{array}$ \\
\hline & $\begin{array}{l}\text { Structured formal family treatments: family group conferencing, behavioural } \\
\text { family therapy, systematic family therapy, intensive family support. }\end{array}$ \\
\hline \multirow[t]{3}{*}{ Medium } & Support for partner and family members to help meet their own needs; \\
\hline & Engage in separate work with different family members; \\
\hline & Referral of family members to other services for support. \\
\hline \multirow[t]{6}{*}{ Low } & Engage mother about the impact of their mental illness on their child; \\
\hline & Directly supporting the mother to parent; \\
\hline & Supporting the mother-infant relationship; \\
\hline & $\begin{array}{l}\text { Supporting the child via the parent such as, interventions which are solely } \\
\text { mother focused; }\end{array}$ \\
\hline & Provide psychoeducation to the mother; \\
\hline & Providing information to the partner, to support the mother. \\
\hline
\end{tabular}

*Family and family members in the context of these activities is defined broadly, it may refer to mothers, fathers, partners, their dependent children (18 or under), and other adult family members. 


\begin{tabular}{|c|c|c|c|c|c|c|}
\hline $\begin{array}{l}\text { Author, } \\
\text { country, } \\
\text { quality } \\
\text { appraisal } \\
\text { score, and FFP } \\
\text { rating }\end{array}$ & $\begin{array}{l}\text { Study } \\
\text { design }\end{array}$ & $\begin{array}{l}\text { Methods of } \\
\text { data } \\
\text { collection }\end{array}$ & $\begin{array}{l}\text { Participant } \\
\text { characteristics }\end{array}$ & $\begin{array}{l}\text { Terminology } \\
\text { used to } \\
\text { describe } \\
\text { mental illness } \\
\text { under } \\
\text { investigation }\end{array}$ & Aims & Findings \\
\hline $\begin{array}{l}\text { LeCroy \& } \\
\text { Whitaker } \\
(2005), \text { USA } \\
(12 / 14) \\
(2 / 35)\end{array}$ & $\begin{array}{l}\text { Mixed } \\
\text { methods }\end{array}$ & $\begin{array}{l}\text { Focus group } \\
\text { and a survey }\end{array}$ & Home visitors $(n=91)$ & $\begin{array}{l}\text { "Mental } \\
\text { illness", } \\
\text { "substance } \\
\text { misuse", and } \\
\text { "mental health } \\
\text { problems". }\end{array}$ & $\begin{array}{l}\text { To use an } \\
\text { ecological } \\
\text { assessment model } \\
\text { to obtain a better } \\
\text { understanding of } \\
\text { difficult situations } \\
\text { that home visitors } \\
\text { confront when } \\
\text { implementing } \\
\text { home visitation } \\
\text { services. }\end{array}$ & $\begin{array}{l}\text { Home visitors found working with limited } \\
\text { resources the most difficult part of the job; } \\
\text { Difficulties arose when substance use was } \\
\text { present and when working with } \\
\text { uncommitted or unmotivated families; } \\
\text { - Difficulties arose when working with } \\
\text { families who were in constant crisis; } \\
\text { - Over } 80 \% \text { of home visitors had confronted } \\
\text { domestic violence, substance abuse, and } \\
\text { mental illness. }\end{array}$ \\
\hline $\begin{array}{l}\text { Borglin et al., } \\
(2015), \text { Sweden } \\
(11 / 14) \\
(3 / 35)\end{array}$ & $\begin{array}{l}\text { Qualitative - } \\
\text { descriptive } \\
\text { design and } \\
\text { content } \\
\text { analysis }\end{array}$ & $\begin{array}{l}\text { Semi- } \\
\text { structured } \\
\text { interviews }\end{array}$ & $\begin{array}{l}\text { Public health nurses } \\
(\mathrm{n}=8) .\end{array}$ & $\begin{array}{l}\text { "Mental ill } \\
\text { health", and } \\
\text { "mental } \\
\text { health". }\end{array}$ & $\begin{array}{l}\text { Investigated public } \\
\text { health nurses' } \\
\text { (PHN) perceptions } \\
\text { and experiences of } \\
\text { mental health and } \\
\text { of preventing } \\
\text { mental ill health } \\
\text { among women } \\
\text { postpartum. }\end{array}$ & 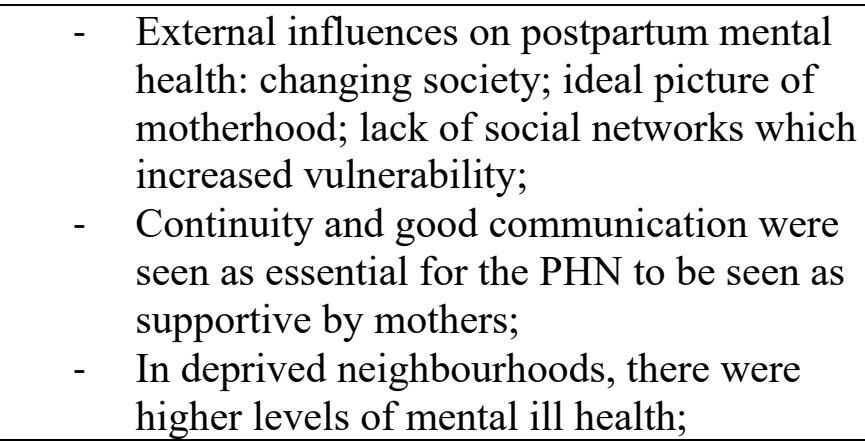 \\
\hline
\end{tabular}




\begin{tabular}{|c|c|c|c|c|c|c|}
\hline & & & & & & $\begin{array}{l}\text { There are inherent difficulties in screening } \\
\text { for and preventing postpartum mental ill } \\
\text { health. }\end{array}$ \\
\hline $\begin{array}{l}\text { Drennan \& } \\
\text { Joseph }(2005) \\
\text { UK } \\
(11 / 14) \\
(3 / 35)\end{array}$ & $\begin{array}{l}\text { Qualitative - } \\
\text { exploratory }\end{array}$ & $\begin{array}{l}\text { Semi- } \\
\text { structured } \\
\text { interviews }\end{array}$ & Health visitors $(n=13)$. & $\begin{array}{l}\text { "Mental } \\
\text { health } \\
\text { problems". }\end{array}$ & $\begin{array}{l}\text { Describe health } \\
\text { visitors' } \\
\text { experiences } \\
\text { working in Inner } \\
\text { London and } \\
\text { identifying and } \\
\text { addressing the } \\
\text { health needs of } \\
\text { refugee woman in } \\
\text { the first } 3 \text { months } \\
\text { after the birth of a } \\
\text { baby. }\end{array}$ & $\begin{array}{l}\text { - Complexity of the relationship between } \\
\text { health visitors and clients who are } \\
\text { refugees; } \\
\text { - Health visitors acknowledged that they are } \\
\text { more likely to prioritise the child's needs } \\
\text { over the mothers; } \\
\text { - Health visitors perceived successful } \\
\text { outcomes of their work rewarding; } \\
\text { - Health visitors described working with } \\
\text { asylum seekers and refugees as being } \\
\text { emotionally difficult. }\end{array}$ \\
\hline $\begin{array}{l}\text { Orford et al., } \\
(2007), \text { UK } \\
(11 / 14) \\
(10 / 35)\end{array}$ & $\begin{array}{l}\text { Qualitative - } \\
\text { Exploratory }\end{array}$ & $\begin{array}{l}\text { Semi- } \\
\text { structured } \\
\text { interviews }\end{array}$ & $\begin{array}{l}\text { GPs }(n=61) ; \text { Health } \\
\text { visitors }(n=69) ; \\
\text { Practice nurses } \\
(n=38) .\end{array}$ & $\begin{array}{l}\text { "Substance } \\
\text { misuse } \\
\text { problems". }\end{array}$ & $\begin{array}{l}\text { Presents the views } \\
\text { of participating } \\
\text { professionals } \\
\text { regarding the value } \\
\text { of the intervention } \\
\text { ( } 5 \text { step } \\
\text { intervention), the } \\
\text { difficulties in } \\
\text { carrying it out, and } \\
\text { the prospects for its } \\
\text { future use in } \\
\text { primary care. }\end{array}$ & $\begin{array}{l}\text { - Most professionals had not worked with } \\
\text { family members in relation to substance } \\
\text { misuse, although they knew it was an } \\
\text { issue; } \\
\text { - Professionals perceived a lack of time to } \\
\text { work with family members; } \\
\text { - Family member may present as having } \\
\text { physical, psychological problems, before it } \\
\text { is known that there is problems in coping } \\
\text { with excessive drinking or drug taking of a } \\
\text { relative. }\end{array}$ \\
\hline $\begin{array}{l}\text { Belle \& Willis } \\
(2013) \\
\text { Australia } \\
(10 / 14) \\
(2 / 35)\end{array}$ & $\begin{array}{l}\text { Qualitative - } \\
\text { interpretive }\end{array}$ & $\begin{array}{l}\text { Semi- } \\
\text { structured } \\
\text { interviews }\end{array}$ & $\begin{array}{l}\text { Child and family } \\
\text { health nurses }(n=10) \text {. }\end{array}$ & $\begin{array}{l}\text { "Postnatal } \\
\text { depression } \\
\text { (PND)", and } \\
\text { "maternal } \\
\text { sadness", }\end{array}$ & $\begin{array}{l}\text { Child and family } \\
\text { health nurse's } \\
\text { (CHNs) } \\
\text { perceptions and } \\
\text { understanding of }\end{array}$ & $\begin{array}{l}\text { CHNs hold an alternative understandings } \\
\text { of maternal sadness which is distinct from } \\
\text { the dominant medical understanding; } \\
\text { - The understandings of maternal distress } \\
\text { held by CHNs enabled them to identify }\end{array}$ \\
\hline
\end{tabular}




\begin{tabular}{|c|c|c|c|c|c|c|}
\hline & & & & & $\begin{array}{l}\text { women's emotional } \\
\text { issues after child } \\
\text { birth and how these } \\
\text { inform their } \\
\text { practice. }\end{array}$ & $\begin{array}{l}\text { women's psychosocial needs within the } \\
\text { broad context; } \\
\text { - CHN draw upon practice expertise and } \\
\text { experience in assessing and managing } \\
\text { PND; } \\
\text { - CHNs have a specialist knowledge base } \\
\text { that enables them to exercise autonomy. }\end{array}$ \\
\hline $\begin{array}{l}\text { Chew-Graham, } \\
\text { et al., (2009), } \\
\text { UK (10/14) } \\
(2 / 35)\end{array}$ & $\begin{array}{l}\text { Nested } \\
\text { Qualitative } \\
\text { study }\end{array}$ & $\begin{array}{l}\text { Semi- } \\
\text { structured } \\
\text { interviews }\end{array}$ & $\begin{array}{l}\text { GPs }(n=19) ; \text { Health } \\
\text { visitors }(n=14) ; \\
\text { Women }(n=28), \\
\text { participating in a } \\
\text { randomised controlled } \\
\text { trial. }\end{array}$ & $\begin{array}{l}\text { "Postnatal } \\
\text { depression". }\end{array}$ & $\begin{array}{l}\text { Explore views } \\
\text { about how } \\
\text { disclosure of } \\
\text { symptoms of } \\
\text { postnatal } \\
\text { depression might } \\
\text { be facilitated or } \\
\text { hindered during the } \\
\text { primary care } \\
\text { consultation. }\end{array}$ & $\begin{array}{l}\text { - If a GP is perceived as not willing to listen, } \\
\text { this inhibited a women's ability to disclose } \\
\text { PND; } \\
\text { - Both GPs and health visitors described the } \\
\text { current systems of care as hindering } \\
\text { disclosure of symptoms of postnatal } \\
\text { depression; } \\
\text { - Women may decide not to seek help with } \\
\text { their symptoms and distress if they thought } \\
\text { that medication would be the only } \\
\text { treatment; } \\
\text { - A whole systems approach would facilitate } \\
\text { women's willingness to disclose. }\end{array}$ \\
\hline $\begin{array}{l}\text { Rollans et al., } \\
(2013), \\
\text { Australia } \\
(10 / 14) \\
(3 / 35)\end{array}$ & $\begin{array}{l}\text { Qualitative- } \\
\text { Ethnographic }\end{array}$ & $\begin{array}{l}\text { Observation } \\
\text { and discussion } \\
\text { groups }\end{array}$ & $\begin{array}{l}\text { Child and Family } \\
\text { Health Nurses } \\
(\text { CFHNs })(n=83) \text {. }\end{array}$ & $\begin{array}{l}\text { "Postnatal } \\
\text { depression". } \\
\text { "poor perinatal } \\
\text { mental health", } \\
\text { and "mental } \\
\text { health } \\
\text { problems". }\end{array}$ & $\begin{array}{l}\text { Examines the } \\
\text { approach (actions } \\
\text { and interactions) } \\
\text { that CFHNs take to } \\
\text { conduct } \\
\text { psychosocial } \\
\text { assessment and } \\
\text { screening in the } \\
\text { early postnatal } \\
\text { period. }\end{array}$ & $\begin{array}{l}\text { - Nurses prioritised establishing a rapport } \\
\text { with the woman during initial visits; } \\
\text { - Nurses utilise intuition and expertise in the } \\
\text { assessment of a women's social and } \\
\text { emotional well-being; } \\
\text { - Tools for assessment and screening may be } \\
\text { limiting if they are the only approach used } \\
\text { to assessment; } \\
\text { - Home visits are crucial in the assessment } \\
\text { of the woman and any 'risk' to the infant } \\
\text { also included observing the home } \\
\text { environment. }\end{array}$ \\
\hline
\end{tabular}




\begin{tabular}{|c|c|c|c|c|c|c|}
\hline $\begin{array}{l}\text { Zeanah et al., } \\
(2006), \text { USA } \\
(10 / 14) \\
(3 / 35)\end{array}$ & $\begin{array}{l}\text { Qualitative - } \\
\text { Grounded } \\
\text { theory }\end{array}$ & $\begin{array}{l}\text { Focus group } \\
\text { and a } \\
\text { questionnaire }\end{array}$ & Nurses $(n=9)$. & $\begin{array}{l}\text { "Mental } \\
\text { health } \\
\text { problems", } \\
\text { "mental health } \\
\text { issues", } \\
\text { "mental health } \\
\text { diagnoses", } \\
\text { "mental health } \\
\text { conditions", } \\
\text { "mental } \\
\text { disorders", and } \\
\text { "mental health } \\
\text { concerns" }\end{array}$ & $\begin{array}{l}\text { To explore nurses' } \\
\text { experiences in the } \\
\text { Louisiana } \\
\text { Nurse Family } \\
\text { Partnership, } \\
\text { capturing both the } \\
\text { potential impact of } \\
\text { augmenting nurse } \\
\text { teams with a } \\
\text { mental health } \\
\text { professional and } \\
\text { cataloguing the } \\
\text { nurses' personal } \\
\text { reflections. }\end{array}$ & $\begin{array}{l}\text { - Mental health problems impacted the } \\
\text { average case load of } 15 \text { to } 20 \text { families } \\
\text { served; } \\
\text { - There are varying degrees of confidence in } \\
\text { recognising mental health diagnoses; } \\
\text { - The emotional impact of the work; } \\
\text { - } \quad \text { Relationships formed with mothers and } \\
\text { their babies were rewarding. }\end{array}$ \\
\hline $\begin{array}{l}\text { Chew-Graham, } \\
\text { et al., (2008), } \\
\text { UK } \\
(9 / 14) \\
(2 / 35)\end{array}$ & $\begin{array}{l}\text { A nested } \\
\text { qualitative } \\
\text { study }\end{array}$ & $\begin{array}{l}\text { Semi- } \\
\text { structured } \\
\text { interviews }\end{array}$ & $\begin{array}{l}\text { GP's }(n=19) ; \text { Health } \\
\text { visitors }(n=14) \text {. }\end{array}$ & $\begin{array}{l}\text { "Postnatal } \\
\text { depression". }\end{array}$ & $\begin{array}{l}\text { To explore the } \\
\text { views of GPs and } \\
\text { health visitors on } \\
\text { the diagnosis and } \\
\text { management of } \\
\text { postnatal } \\
\text { depression. }\end{array}$ & $\begin{array}{l}\text { - GP and health visitors attribute a } \\
\text { psychosocial aetiology to postnatal } \\
\text { depression; } \\
\text { - } \quad \text { Ambivalence about the status of postnatal } \\
\text { depression as a separate condition; } \\
\text { - } \quad \text { Lack of resources for referral to other } \\
\text { services; } \\
\text { - Ambivalence from health visitors and GPs } \\
\text { about each other's role in PND } \\
\text { management; } \\
\text { - Organisational changes impact on patient } \\
\text { care with no one taking overall } \\
\text { responsibility for women with PND. }\end{array}$ \\
\hline $\begin{array}{l}\text { Moy, et al., } \\
(2007), \text { UK } \\
(9 / 14)\end{array}$ & $\begin{array}{l}\text { Qualitative - } \\
\text { inductive }\end{array}$ & $\begin{array}{l}\text { Reflective } \\
\text { accounts of } \\
\text { professionals }\end{array}$ & $\begin{array}{l}\text { Community midwife } \\
(\mathrm{n}=1) ; \text { Public Health } \\
\text { Nurse }(\mathrm{n}=1) \text {; General }\end{array}$ & $\begin{array}{l}\text { "Drug } \\
\text { misuse". }\end{array}$ & $\begin{array}{l}\text { To explore the } \\
\text { challenges health } \\
\text { professionals }\end{array}$ & $\begin{array}{l}\text { During the initial care stages specialist } \\
\text { addictions support and co-ordination of } \\
\text { health and social care is crucial; }\end{array}$ \\
\hline
\end{tabular}




\begin{tabular}{|c|c|c|c|c|c|c|}
\hline$(11 / 35)$ & & & $\begin{array}{l}\text { Practitioner }(\mathrm{n}=1) \\
\text { Specialist Addiction } \\
\text { Nurse }(\mathrm{n}=1) .\end{array}$ & & $\begin{array}{l}\text { encounter } \\
\text { supporting families } \\
\text { of drug misusers, } \\
\text { with parenting } \\
\text { responsibilities. }\end{array}$ & $\begin{array}{l}\text { - Professional differences in emphasis } \\
\text { between those who focus on the } \\
\text { parent/child unit, and those who } \\
\text { differentiate between needs of the adult } \\
\text { and the child; } \\
\text { - Professionals should have the opportunity } \\
\text { to identify and access training regarding } \\
\text { drug-using parents. }\end{array}$ \\
\hline $\begin{array}{l}\text { Psaila et al., } \\
(2014), \\
\text { Australia } \\
(8 / 14) \\
(2 / 35)\end{array}$ & $\begin{array}{l}\text { Mixed } \\
\text { methods - } \\
\text { qualitative } \\
\text { component } \\
\text { was } \\
\text { interpretive }\end{array}$ & $\begin{array}{l}\text { Focus group, } \\
\text { survey, and } \\
\text { semi- } \\
\text { structured } \\
\text { interviews }\end{array}$ & $\begin{array}{l}\text { Participants }(\mathrm{n}=33) \\
\text { included: managers, } \\
\text { CFH nurses, } \\
\text { midwives, GPs, } \\
\text { support workers, } \\
\text { allied health, } \\
\text { Aboriginal health } \\
\text { workers and } \\
\text { community health } \\
\text { professionals. }\end{array}$ & $\begin{array}{l}\text { "Mental } \\
\text { health } \\
\text { problems". }\end{array}$ & $\begin{array}{l}\text { To describe } \\
\text { innovations to } \\
\text { improve continuity } \\
\text { for women and } \\
\text { their babies, } \\
\text { focused on the } \\
\text { transition between } \\
\text { maternity and } \\
\text { Child and Family } \\
\text { Health }(\mathrm{CFH}) \\
\text { services. }\end{array}$ & $\begin{array}{l}\text { CFH work together with maternity teams } \\
\text { to provide continuity for mothers with } \\
\text { mental health problems; } \\
\text { - Effective innovations need to reinforce: } \\
\text { collaborating for change, connecting early, } \\
\text { and a team approach and flexibility; } \\
\text { - Multi-disciplinary collaboration was } \\
\text { essential for effective transition of mothers } \\
\text { with mental health problems from } \\
\text { maternity to CFH services. }\end{array}$ \\
\hline $\begin{array}{l}\text { Whittaker et al., } \\
(2016), \text { UK } \\
(8 / 14) \\
(6 / 35)\end{array}$ & $\begin{array}{l}\text { Qualitative - } \\
\text { exploratory }\end{array}$ & Focus group & $\begin{array}{l}\text { GPs }(n=3) ; \\
\text { Community Midwives } \\
(n=4) ; \text { Public Health } \\
\text { Nurses }(n=3) ; \\
\text { Community } \\
\text { Addiction Nurses } \\
(n=5) ; \text { Consultant } \\
\text { Psychiatrist }(n=1) \text {. }\end{array}$ & $\begin{array}{l}\text { "Drug } \\
\text { misuse". }\end{array}$ & $\begin{array}{l}\text { To explore the } \\
\text { views and } \\
\text { experiences of } \\
\text { healthcare } \\
\text { professionals in } \\
\text { relation to } \\
\text { providing parenting } \\
\text { support for drug- } \\
\text { using parents. }\end{array}$ & 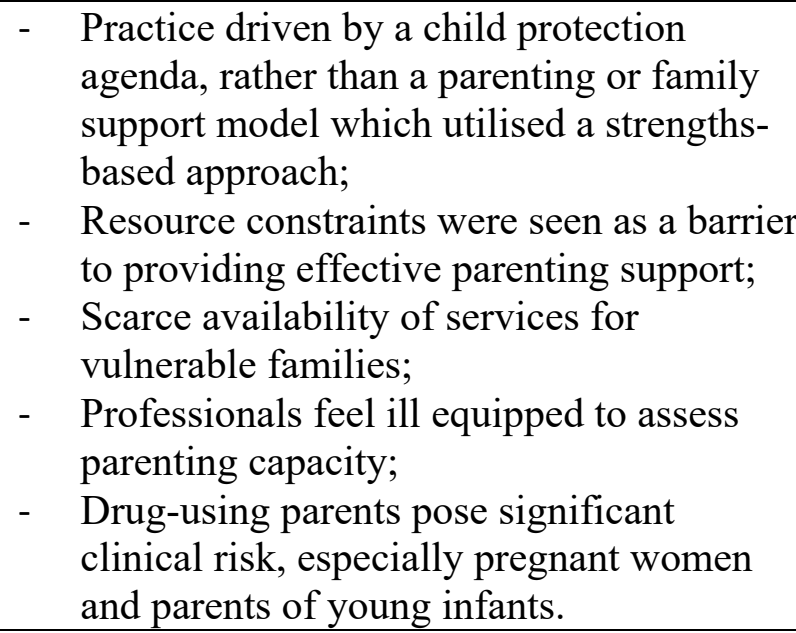 \\
\hline
\end{tabular}




\begin{tabular}{|c|c|c|c|c|c|c|}
\hline $\begin{array}{l}\text { McIntosh \& } \\
\text { Shute (2007), } \\
\text { UK } \\
(7 / 14) \\
(2 / 35)\end{array}$ & $\begin{array}{l}\text { Qualitative - } \\
\text { longitudinal }\end{array}$ & $\begin{array}{l}\text { Semi- } \\
\text { structured } \\
\text { interviews }\end{array}$ & $\begin{array}{l}\text { Health visitors }(n=14) \text {; } \\
\text { First-time and } \\
\text { experienced mothers } \\
(n=13) \text {. }\end{array}$ & $\begin{array}{l}\text { "Mental } \\
\text { health". }\end{array}$ & $\begin{array}{l}\text { To gain insight into } \\
\text { aspects of the } \\
\text { Starting Well } \\
\text { demonstration } \\
\text { project, programme } \\
\text { delivery, how the } \\
\text { programme was } \\
\text { operationalised 'on } \\
\text { the ground' and } \\
\text { how it was } \\
\text { experienced by } \\
\text { parents. }\end{array}$ & $\begin{array}{l}\text { Most mothers appreciate intensive levels } \\
\text { of support in the first few weeks of their } \\
\text { infant's life; } \\
\text { - Value of the relationship built over time in } \\
\text { developing trust; } \\
\text { - Services located in the home, facilitated an } \\
\text { intimate knowledge of family problems } \\
\text { and styles of parenting; } \\
\text { - Person-centred and non-directive approach } \\
\text { to providing support is more likely to } \\
\text { secure mothers' engagement. }\end{array}$ \\
\hline $\begin{array}{l}\text { Tammentie et } \\
\text { al., (2013), } \\
\text { Finland } \\
(5 / 14) \\
(6 / 35)\end{array}$ & $\begin{array}{l}\text { Qualitative - } \\
\text { Grounded } \\
\text { theory }\end{array}$ & $\begin{array}{l}\text { Open } \\
\text { interviews }\end{array}$ & $\begin{array}{l}\text { Public health nurses } \\
(\mathrm{n}=14) .\end{array}$ & $\begin{array}{l}\text { "Postnatal } \\
\text { depression". }\end{array}$ & $\begin{array}{l}\text { To explore the } \\
\text { experiences of } \\
\text { PHNs and their } \\
\text { interaction with } \\
\text { families at a child } \\
\text { health clinic in } \\
\text { connection with } \\
\text { mothers } \\
\text { experiencing PND. }\end{array}$ & $\begin{array}{l}\text { - Listening to the parents is an essential part } \\
\text { of the family's visit; } \\
\text { - Flexibility in appointments helps mothers } \\
\text { and families when they are not doing well; } \\
\text { - The PHN should arrange appointments so } \\
\text { the whole family can attend together; } \\
\text { - Inherent difficulties in identifying PND. }\end{array}$ \\
\hline $\begin{array}{l}\text { Fletcher (2009), } \\
\text { Australia } \\
(2 / 14) \\
(7 / 35)\end{array}$ & $\begin{array}{l}\text { Qualitative - } \\
\text { Case study }\end{array}$ & $\begin{array}{l}\text { Observation } \\
\text { and semi- } \\
\text { structured } \\
\text { interviews }\end{array}$ & Fathers $(n=1)$. & $\begin{array}{l}\text { "Postnatal } \\
\text { depression", } \\
\text { and } \\
\text { "depression". }\end{array}$ & $\begin{array}{l}\text { To illustrate how } \\
\text { supporting the } \\
\text { father, in cases } \\
\text { where mothers } \\
\text { have PND, can } \\
\text { assist in alleviating } \\
\text { symptoms and } \\
\text { improve family } \\
\text { functioning. }\end{array}$ & $\begin{array}{l}\text { - Father-infant and mother-infant } \\
\text { relationships may be assisted by early } \\
\text { intervention services directed at the father; } \\
\text { - Fathers have an important role in their } \\
\text { infant's development but were not } \\
\text { considered as a "helper" to the mother; } \\
\text { - Early intervention with families should } \\
\text { consider the fathers perspective; } \\
\text { - The importance of recognise the fathers' } \\
\text { role in supporting the mother. }\end{array}$ \\
\hline
\end{tabular}

Table 2: Characteristics of included studies 